\title{
THE INTERACTION OF THE OIL AND GAS OFFSHORE INDUSTRY WITH FISHERIES IN BRAZIL: THE "STENA TAY" EXPERIENCE
}

\author{
Silvio Jablonski
}

Universidade do Estado do Rio de Janeiro, Faculdade de Oceanografia (Rua São Francisco Xavier, 524, Bl. E, 20550-013 Rio de Janeiro, RJ, Brasil) jablonski@pobox.com

\begin{abstract}
Most of the oil and natural gas produced in Brazil derive from offshore fields, virtually concentrated in the Campos Basin off the coast of Rio de Janeiro State. The area is also of intense fisheries interest, involving participation of hand-liners artisanal boats and tuna boats due to the fish aggregating effect of the oil rigs. In order to avoid accidents with the platform "Stena Tay", in operation at Santos and Campos Basins, in 2001 e 2002, an awareness project was developed aiming at avoiding the presence of fishing boats in its $500 \mathrm{~m}$ exclusion zone. This paper summarizes the main observations concerning the extent of the fish aggregating effect and the behavior of the fishing boats in the vicinity of the platform.
\end{abstract}

\section{RESUMO}

A maior parte do óleo e do gás produzido no Brasil provém de campos offshore, virtualmente concentrados na bacia de Campos, ao largo da costa do estado do Rio de Janeiro. Na área, em função do efeito de atração de cardumes exercido pelas estruturas de exploração e produção de óleo e gás, ocorrem também importantes pescarias, envolvendo a participação de barcos artesanais, que operam com linha de mão, e atuneiros. De modo a evitar acidentes com a plataforma "Stena Tay", em operação nas bacias de Santos e Campos, em 2001 e 2002, foi desenvolvido um projeto de comunicação visando manter os barcos de pesca fora da área de exclusão de $500 \mathrm{~m}$. Este trabalho apresenta as principais observações acerca da extensão do efeito agregador dos cardumes e do comportamento das embarcações na vizinhança da plataforma.

Descriptors: Oil and gas platforms, Interactions with fisheries, Campos and Santos Basins, Brazil Descritores: Plataformas de óleo e gás, Interações com as pescarias, bacias de Campos e Santos, Brasil.

\section{INTRODUCTION}

Most of the oil $(85 \%)$ and natural gas $(59 \%)$ produced in Brazil derive from offshore fields, virtually concentrated in the Campos basin, off the coast of Rio de Janeiro State. In 2005, the total production from marine fields was 617 million of oil and 112 millions of natural gas, measured in barrel of oil equivalent (boe). Concerning the marine fields, in 2005 , the state of Rio de Janeiro accounted for $96 \%$ of the oil production and $77 \%$ of gas production (ANP, 2006). In the beginning of 2006 , there were more than 60 fixed or floating platforms in activity in the Campos Basin (CLICKMACAE, 2007)

In 1980, the former Superintendency of Fisheries Development (SUDEPE), trying to reduce the traffic and the activity of fishing boats in the area of the Campos Basin, banned "the fishing, with any type of gear, in the area limited by the points of $22^{\circ} 18^{\prime} \mathrm{S}, 40^{\circ} 03^{\prime} 30^{\prime \prime} \mathrm{W} ; 22^{\circ} 08^{\prime} \mathrm{S}, 40^{\circ} 15^{\prime} 30^{\prime \prime} \mathrm{W} ; 22^{\circ} 40^{\prime} \mathrm{S}$, $40^{\circ} 57^{\prime \prime} \mathrm{W}$; and $22^{\circ} 50^{\prime} \mathrm{S}, 40^{\circ} 45^{\prime} 30^{\prime \prime} \mathrm{W}$. The legal statement defined an area approximately rectangular, southeast of Cabo de São Tomé, covering in its great part bathymetry between 100 and $200 \mathrm{~m}$.

In 1993, the exclusion area was increased and the rectangle reached 118 by 40 nautical miles, covering areas with depths greater than $2,000 \mathrm{~m}$. (Fig. 1). Later on, the adoption of the principles recommended by the international and national legislations (UNCLOS, 1982; MARINHA DO BRASIL, 2000) have determined the creation of "safety zones", comprising only an exclusion area 500 $\mathrm{m}$ around each platform or emerging structure.

The safety zones aims to ensure the safety both of navigation and of the installations and structures, avoiding or reducing the probability of accidents caused by the interaction of fishing boats and gears and oil rigs (for instance, the entanglement of longlines in the platform thrusters, or even sparks leading to fire events) 


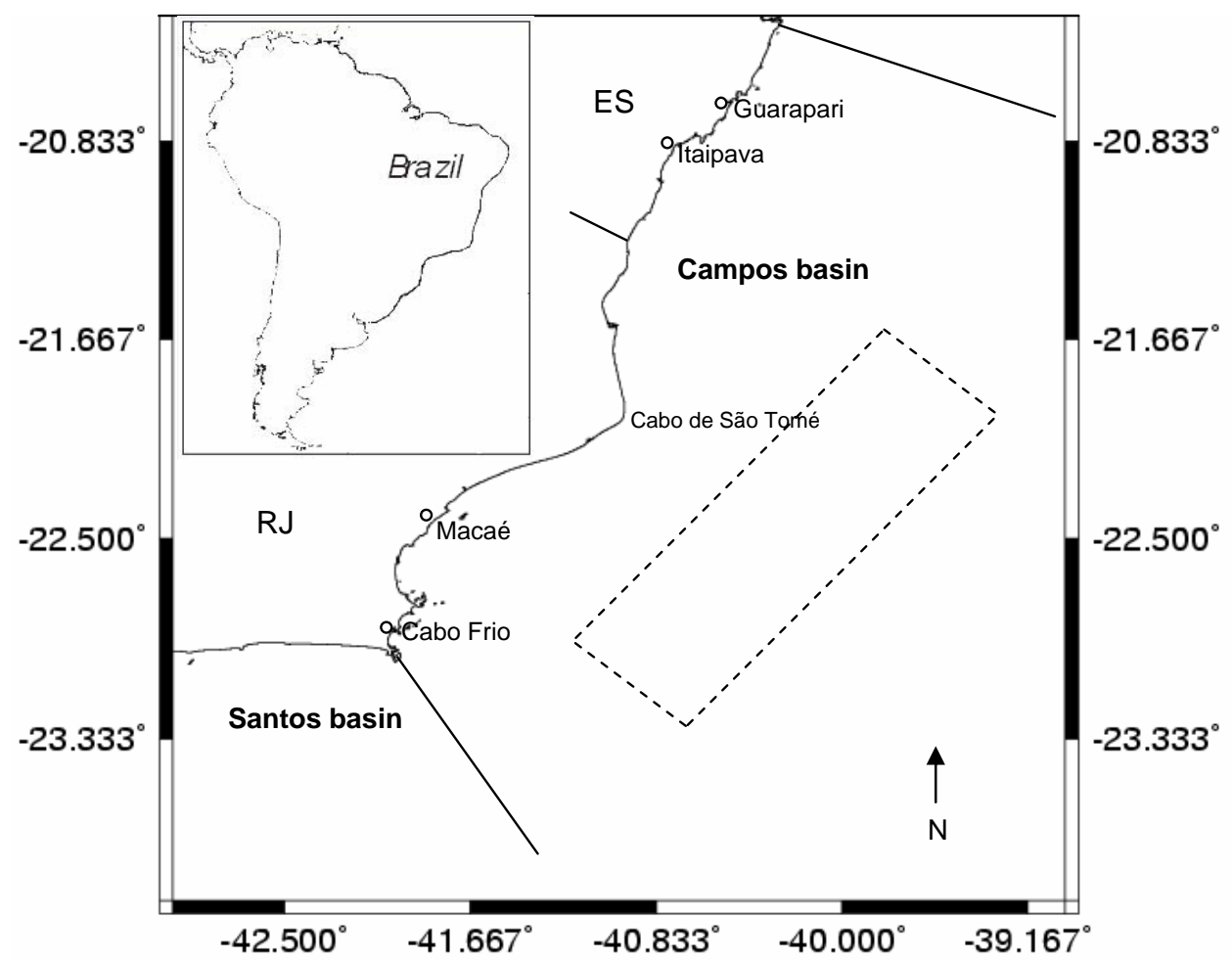

Fig. 1. The former exclusion zone (dotted line) at Campos basin (adapted from Jablonski, 2003).

The exclusion area, despite the legal hindrances to the fisheries operation, attracted several fleets with different fishing gears, due to the aggregating effect on tunas and tuna- like fish of the oil and gas rigs. The pole and line skipjack tuna fishery, implemented in the late 70's, in Rio de Janeiro, adopted the oil rigs region as its main fishing grounds. In 1998 and 1999, respectively, 60\% and $38 \%$ of tuna landed in Rio de Janeiro, came from that area (JABLONSKI, 2003). The number of tuna boats operating in the State is not precisely known, but estimated at 20 to 30 boats (L.H.A. Moreira, IBAMA Brazilian Institute of the Environment and the Renewable Resources, pers. comm.).

The aggregating effect of fixed or drifting devices on tunas is well known (BROMHEAD et al., 2006), and it is a part of the fishing strategies of several fleets. ICCAT (1999) mentions the existence of around 5 thousand fish aggregating devices (FADs), deployed by tuna boats in the Atlantic.

Small artisanal boats operating with hand lines, troll rigs and pelagic longlines also identified the area's fishing potential. Currently, around 170 artisanal fishing boats, with an average length of $12 \mathrm{~m}$, based in Itaipava municipality, in the south of Espírito Santo State, are known to operate in the oil platforms region (MARTINS; DOXSEY, 2006).

In order to avoid accidents with the platform "Stena Tay", in operation at Santos and Campos Basins, in 2001 and 2002, Shell Brasil contracted the "Instituto Brasileiro de Segurança Marítima e Fluvial - SEGUMAR" (Brazilian Institute of Maritime and Riverine Safety), to develop an awareness plan designed to avoid the presence of fishing boats in the platform's $500 \mathrm{~m}$ fishing/navigation exclusion zone. This paper presents a summary of the onboard observations and the behavior of fishing boats, discusses and suggests possible strategies to minimize conflicts in the oil and gas platforms exclusion zones.

\section{Material ANd Methods}

Observers were positioned aboard an auxiliary boat in the neighborhood of the platform. The work was carried out on three successive phases, 
the first between 22 October and 22 December 2001 in the north of the Santos basin $\left(24^{\circ} 06^{\prime} \mathrm{S}\right.$ and $41^{\circ} 53^{\prime} \mathrm{W}$ ), the second (from 27 December 2001 to 30 March 2002) and the third (14 August to 06 September 2002 and 10 September to 22 September 2002), in the Campos Basin $\left(22^{\circ} 40^{\prime} \mathrm{S}\right.$ and $\left.40^{\circ} 12^{\prime} \mathrm{W}\right)$. During the first and second phases, the observers worked in pairs, comprised of one fisherman and one researcher. In the third phase, due to budget limitations, a fisherman and a researcher took turns in successive boardings.

The boat's names and type of fishing gear, as well as starting time (time of first visual contact) and the end of the stay around the platform were registered in specific forms. For the first phase, it was possible to have an estimate of the amounts of fish caught inside and outside the area. The behavior of the fishing crew was classified as "cooperative" or "uncooperative", concerning the willingness to dialogue with the observer team and inform about catches and port of origin, via radio, not reflecting, therefore, the acceptance or not, of the exclusion zone. Radio contacts granted the opportunity for informal conversation between the observers and some fishermen and in such a way allowed the evaluation of fishermen perception about fishing within the exclusive zones.

According to the rules defined by Shell Brasil in relation to the "behavior of the observer team and supply-boat crew", in the necessity of approaching to any fishing boat inside the platform safety zone, the supply or auxiliary boat should keep a safety distance to be established by the captain. Also in order to avoid accidents, the approach speed should be compatible with safety criteria. Any act of hostility or dispute from the crew and/or technicians aboard directed to the fishermen or boats in the exclusion area were strictly forbidden (L. Strada, Segumar Institute, pers. comm.).
Additionally, in the scope of the same work, two meetings with fishermen were organized; the first one in Rio de Janeiro, on 10 December 2001, and the second in Itaipava - ES, on 30 April 2002, with lectures and distribution of flyers with safety instructions to the fishermen. The meetings had the participation of fishermen associations, and representatives of the Brazilian Navy, the National Petroleum Agency - ANP and the Brazilian Institute for the Environment and the Natural Renewable Resources - IBAMA.

\section{Results}

Table 1 shows a brief picture of the main observations.

The tuna boats fishing near the oil platforms operate with pole and line and live-bait. When a tuna or skipjack tuna school is targeted, the bait, generally live juvenile sardines, are thrown to the sea. The fishermen use poles with short lines and barbless hooks and the fishery is a quite rapid process. Landings take place mainly in a fish harbor in Guanabara bay, Rio de Janeiro.

Artisanal boats employ hand-lines and troll rigs. The lines have to be long enough in order to allow the fish to swim until exhaustion without the risk of line rupture. The artisanal fleet use also longlines with 300 to 800 hooks. The secondary lines which hold the hooks to the main line are three fathoms long (around $5.40 \mathrm{~m}$ ) and distant from each other about eight fathoms $(14.4 \mathrm{~m})$. The longlines can be four miles long. The main species caught are king mackerel, tuna and dolphin fish. Landings points are located in south of Espírito Santo and north of Rio de Janeiro.

Table 1. Summary of observations from onboard observers at the "Stena Tay" exclusion area"

\begin{tabular}{ccccccccccc}
\hline \hline \multirow{2}{*}{ Phase } & \multirow{2}{*}{$\begin{array}{c}\text { Duration } \\
\text { (days) }\end{array}$} & \multicolumn{3}{c}{ Occurrences $^{2}$} & & \multicolumn{2}{c}{ Cooperative } & \multicolumn{2}{c}{ Attempts to fish in the area } \\
\cline { 3 - 10 } & & Tuna & Line & Total & Yes & No & Tuna & Line & Total \\
\hline 1 & 62 & $13(7)$ & $4(4)$ & $17(11)$ & 14 & 3 & 11 & 2 & 13 \\
2 & 94 & $6(6)$ & $27(27)$ & $33(33)$ & 16 & 17 & 0 & 14 & 14 \\
3 & 37 & $10(4)$ & $18(7)$ & $28(11)$ & 16 & 12 & 7 & 13 & 20 \\
\hline
\end{tabular}

1 - See text for details.

2 - Numbers show total occurrences, while those between parentheses indicate individual boats. The differences correspond to repeated visits. 
In the first phase, for a total of 62 days of observation, between October and December 2001, 17 occurrences of fishing boats were registered, of which 13 were tuna boats ( 7 different vessels) and four handlines boats (three from Itaipava - ES and one based in Cabo Frio - RJ). While for the hand-liners there was no case of repeated attempts, some tuna boats tried to fish in the exclusion area twice or three times in different occasions. The visits of fishing boats to the platform area were concentrated in 13 days more or less evenly distributed during the observation period. The interval from 6 to 16 December 2001 was the only exception, with no approaches.

The time of permanence around the platform (not necessarily in the exclusion area) was quite variable. The average permanence time of four hours does not seem to represent correctly the fishing boats behavior. Some tuna boats stayed for up to 15 hours in the platform's vicinity. In this case, the median of 1h35min explains more accurately the boat's behavior, indicating that $50 \%$ of the visits were of short duration.

Concerning the behavior towards the team of observers, only three fishing crews (tuna boats) showed behavior classified as "uncooperative". Only two hand-liners and two tuna boats did not attempt to fish in the exclusion area. All the others, despite the verbal contacts and warnings via radio, tried to operate in the exclusion area. Fishing took place either inside as outside the exclusion area of $500 \mathrm{~m}$ but only the tuna boats succeeded to catch. The estimated amounts (based on visual assessments by observers) of fish caught accounted as coming from "inside" the area, "outside" and "both in and out" were, respectively, of $1,300 \mathrm{~kg}, 1,400 \mathrm{~kg}$ and $6,700 \mathrm{~kg}$.

Observations confirmed fish schools of larger densities in the areas adjacent to the platform. Notwithstanding, in some occasions, large tuna schools (probably skipjack-tuna) were observed in distances greater than one nautical mile from the platform. The good catches carried out outside the restriction area also showed the presence of dense schools in a more extended area.

The second observation period was longer than the first amounting 94 days at sea, between December 2001 and March 2002. The presence of 33 fishing boats (six tuna boats and 27 hand-liners), in 25 days of occurrences was registered. The average time around the platform was of 20 minutes. Among the hand-liners, 14 were classified as "cooperative" and 13 as "uncooperative"; for the tuna boats, the ratio was two to four. Between 03 and 14 February, probably due to carnival holidays, there were no occurrences.
Unlike the first phase, when the platform was considerably distant to any other oil exploration or production structure, the new position presented a high density of platforms (there were at least three others similar structures within 2 and 3.5 nautical miles). This characteristic of "abundance" of targets for the fishing boats made the task of convincing the fishermen not to enter the exclusion area easier and possibly explains in part the absence of repeated attempts to fish close to the Stena Tay platform, and also the shorter times of stay in the area. As at the other platforms there were no impediment for the fishing activity, it was not reasonable for the boats to insist to fish in the Stena Tay's exclusion area.

Differently from the previous location, the small hand-liners were observed in greater number than the tuna boats. Therefore the boats based in Rio de Janeiro (home base for almost all tuna boats operating in the Santos and Campos basins), dominant in the first phase, gave place to the fishing boats from Espírito Santo and from the north of Rio de Janeiro state. An important part of the these boats came from Itaipava-ES (seven), and at least in three opportunities, boats from Guarapari-ES, Macaé and Cabo Frio-RJ informed that the crews were recruited in Itaipava-ES. Six hand-liners could not be identified because their names were wiped off, covered or not visible.

Whilst tuna boats did not attempt to fish in the exclusion area, among the hand-liners 14 operated in the area and 13 decided not to fish within the 500 $\mathrm{m}$.

The third phase was shorter, extending for 37 days, divided in two periods, respectively, of 24 days, from 14 August to 06 September 2002, and of 13 days, between 10 and 22 September 2002. There were fishing boats approaches only in 12 days, corresponding to 28 occurrences (10 tuna boats and 18 hand-liners). In six cases concerning the tuna boats and in 10 cases, for the hand-liners, the boats were classified as "cooperative". In relation to fishing within the exclusion area, only three tuna boats and five hand-liners were persuaded not to fish.

Considering the whole observation period, fishing boats had in general a friendly attitude with occasional or even involuntary entries in the restriction area. Nevertheless this picture was drastically altered between 08 and 11 September, when boats most of them hand-liners based in Espírito Santo, operated aggressively, with approaches as close as $10 \mathrm{~m}$ of the platform. The events which happened on 08 and 09 September were reported by the Stena Tay crew, while those of 10 and 11 September, including the presence and behavior of boats were informed by the onboard observer. 
For most of the approaching attempts, during the three phases, warnings via radio or loudspeaker were enough to persuade fishing boats to leave the exclusion area. Nevertheless, in a few cases it was necessary to interpose the supply or auxiliary boat between the platform and the fishing boat. Figures 2, 3 and 4 show, respectively, a hand-liner and a tuna boat operating very close to the platform and the interference of the auxiliary boat being positioned so as to avoid further approach by the tuna boat.

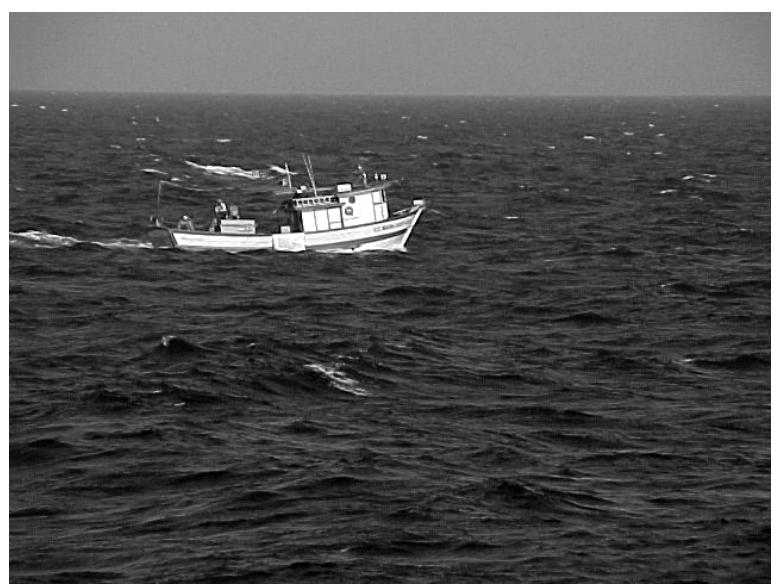

Fig. 2. Hand-line and trolling fishing close to Stena Tay. Campos basin, 2001. Photo: SEGUMAR Institute.

Fig. 3. Live bait-boat fishing for skipjack tuna close to Stena Tay. Santos basin, 2001. Photo: SEGUMAR Institute.

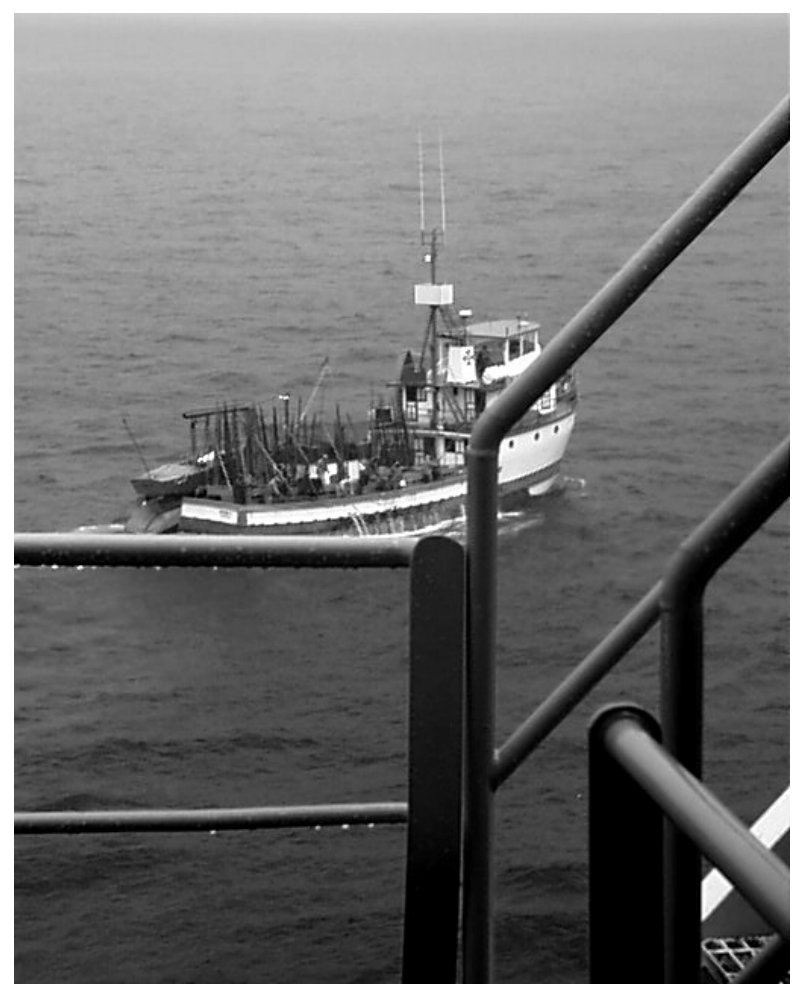




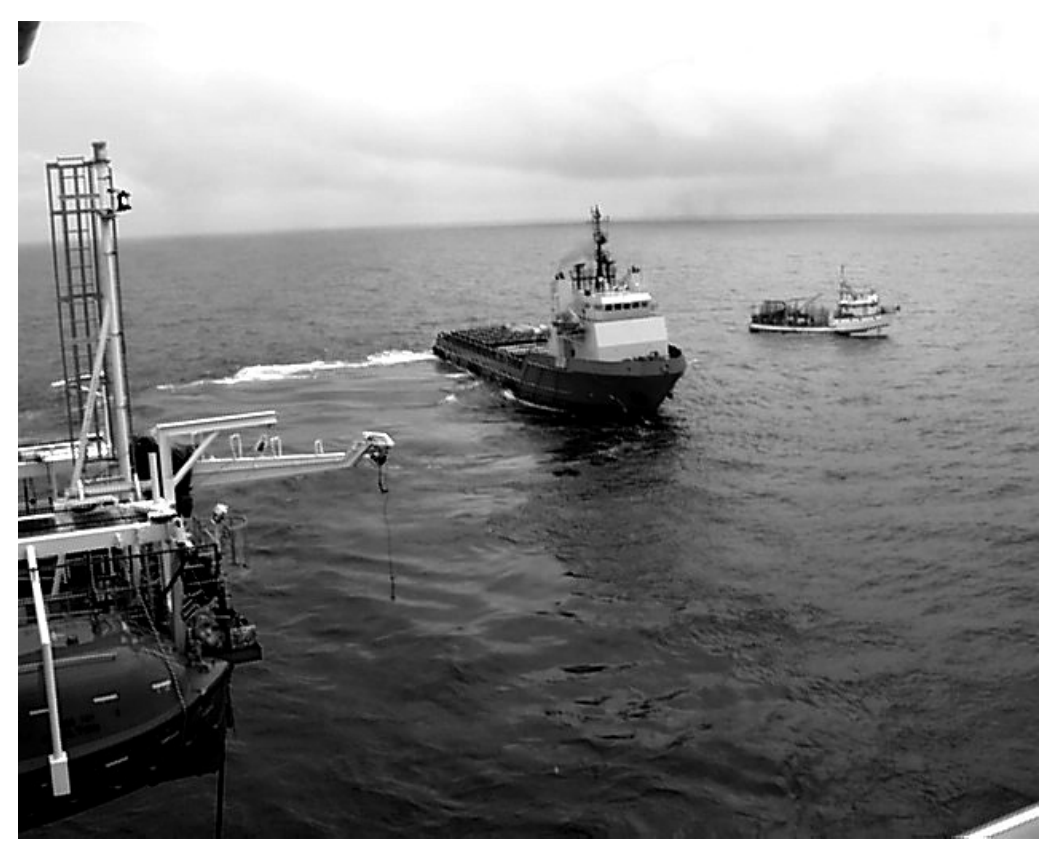

Fig. 4. Supply-boat positioned between the platform and the tuna live bait-boat. Santos basin, 2001. Photo: SEGUMAR Institute.

In each observation period, some fishing boats made repeated attempts to fish in the exclusion area, on the same day or in different days. However, when considering the approaches for the three phases, only a few boats were recorded in more than one phase - two tuna boats were present in both periods: one and two, and one and three; and only one hand-liner was present in phases two and three. During the three phases, 78 occurrences were registered, involving 38 different hand-liners and 12 tuna boats.

\section{DisCUSSION}

The observations during the three working phases helped to clarify some aspects related to the platforms fish aggregating effect. Immediately after the arrival and placement of the platform, it was already possible to observe the fish-aggregating effect in its vicinity. Practically no time interval was necessary for the fish aggregation become quite evident. The same process has already been noticed in relation to drifting FADs. Experiments have demonstrated that large numbers of tuna may aggregate soon after deployment, and in some cases this period being only a matter of hours, and in others a few days (BROMHEAD et al., 2006).
The denser schools were observed within the exclusion area and, in some cases less than $50 \mathrm{~m}$ from the platform. However, the aggregating effect of the structures apparently do not wear out in the their immediate vicinity, extending also to the adjacent regions, which explains good catches of the tuna boats outside the area registered during the first working phase.

The three periods of work at sea had different durations (62, 94 and 37 days), and also different averages of fishing boats occurrences $(0.27$, 0.35 and 0.76 approaches/day).

The percentage of fishing attempts in the exclusion area (related to the total number of occurrences in the platform near by) were variable between phases but did not show any clear trend. For the hand-liners, the percentages of invasion of the restriction area were, respectively, of $50 \%, 52 \%$ and $72 \%$, in each phase. The percentages for the tuna boats were $85 \%$, in the first and $70 \%$ in the third period, while during the second phase none of the six tuna boats observed tried to come inside the exclusion area.

Figure 5 shows the timeline for the three periods and also indicates the meetings with fishermen. The first one in Rio de Janeiro, in December 2001, at the tuna boats landing point, could have contributed for the more friendly and receptive behavior for those boats during phase two. Yet, the 
second, held in Espírito Santo State and aimed at the hand-line fishermen, occurred one month after the end of second phase and three and a half months before the third phase. This time lag could have led to attenuate the meeting's positive effect or indicate a different approach for the ES fishermen.

The different locations of the three phases specially the first one relatively isolated in the Santos Basin turned difficult to assess the fishing boats behavior. The displacement of the platform after phase one to the Campos Basin changed the visiting fishing boats profile, mainly in the second period, with the predominance of hand-liners from Espírito Santo and north of Rio de Janeiro. However this was not the only new variable; the vicinity to other platforms in the region could have explained the immediate departure of the fishing boats from the area to look for new "targets" in the neighborhood after the first contact with the observer team.

While the repeated visits of some fishing boats to the exclusion area were common during phases one and three, these events were rare as far two successive or alternate phases are concerned. It is possible that due to the size of the potential fishing ground and the presence of dozens of platforms in the region, the boats could have avoided the proximity of Stena Tay, the only one bearing a deterrence arrangement. The more aggressive behavior occurred during phase three and involved boats, most of them hand-liners, which until then had not operated next to Stena Tay.

During radio contacts with the fishermen trying to operate near the platform, it was possible to identify common reasoning points. The presence of a fisherman in the observer team made the contacts easier and the dialogues more fluent.

The fisheries close to the platforms were justified for their characterization as "good fishing grounds". In some opportunities, it was noted that according to the fishermen's perception platforms do not aggregate fish, but they were placed exactly in the "best fishing grounds", suggesting a possible "occupation" of the existing fishing grounds.

Tuna boat skippers particularly do not perceive any risk potential to the platforms or to their vessels as a result of fishing closely to the structures, because of the features of their fishing gear (poles and short lines each one with a single hook). After the first contact and probably due to the presence of a fisherman in the observer team, a "cooperative" attitude for the dialogue via radio prevailed among the tuna boat skippers. Nevertheless in $60 \%$ of the cases, they decided to overrun the restriction area. This seems to suggest that in the fishermen's perception, fishing in the exclusion area is a "minor" infraction or even a low risk one regarding fines or other penalties, because of the inefficiency or even lack of control.

On the other side, it is important to note that in the case of hand-liners and in a little less than half of the tuna boats, warnings via radio or loudspeaker were enough for the boats to leave the area and keep fishing outside the restriction zone, what can suggest the possible efficiency of awareness campaigns if carried out systematically.

Another difficulty observed from the contacts with the fishing boats was related to the precarious communication and positioning equipment available onboard, mainly among hand-liners. These, hardly have the necessary conditions to determine their precise distance in relation to a fixed point. In some cases the most cooperative skippers asked the observers to keep them informed in relation to any crossing of the $500 \mathrm{~m}$ line. This should require that the platform or the auxiliary boat crews keep checking out the routes of the fishing boats and warn them concerning the limits of the fishing/navigation exclusion area.

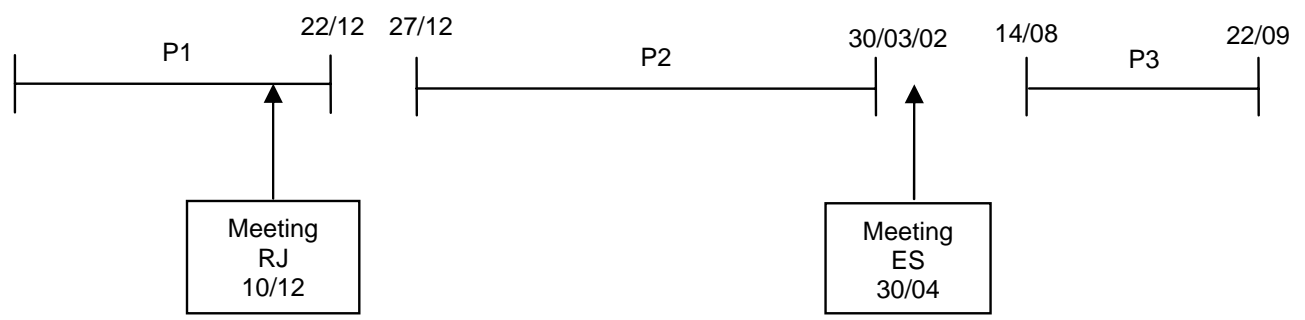

Fig. 5. Timeline showing the duration of each phase and the meetings with the fishermen in Rio de Janeiro (RJ) and Espírito Santo (ES).

P1, P2, P3 - Phases 1, 2 and 3 


\section{Conclusions}

The reduction of the problem brought about by the fishing pattern adopted by hand-liners and tunaboats near the platforms should include activities in different levels, combining awareness work directed to the fishing communities and fishermen associations, with eventually more "repressive" actions (filming or photographing the boats within the restricted areas and reporting to the Naval authorities).

The work at sea certainly will lead to more immediate results related to the effectiveness of the restriction areas. However, only a process of consciousness raising aimed at the fishermen can probably guarantee the project success in the long range. This will require a systematic effort to carry out lectures and discussions with the communities involved in each of the main landing points. It is important to notice that the fish aggregating effect of the structures seemed to extend beyond the exclusion area $500 \mathrm{~m}$ around the platform.

In the case of tuna boats, the work can be done through direct contact with shipowners and, particularly, with skippers, ultimately responsible for choosing the fishing areas. However, for the artisanal hand-liners, local efforts will be necessary, to persuade fishermen in communities north of Rio de Janeiro and south of Espírito Santo States. Despite their small sizes, these boats are potentially more hazardous to platform equipment, due to the length of the fishing lines and number of hooks they operate, as opposed to the tuna-boats.

\section{AcKNOWLEDGEMENTS}

I thank SHELL BRASIL and SEGUMAR Instituto Brasileiro de Segurança Marítima e Fluvial -for providing the database corresponding to the three periods of observation in the exclusion area of the Stena Tay, and Dr. Jorge Pablo Castello for valuable comments on an earlier version of the manuscript. Special thanks are due to the onboard observers Daniel Nunes, Daniel Viana, Everaldo da Cunha Lima, João Marcelo Silva de Souza, Marcelo Mota de Azevedo, Marcio Almeida Magalhães, Paulo Renato Dorneles, Rafael da Cunha Moraes, Raphael Sims and Rubens Roberto Monegalha. Philip Conrad Scott helped in the translation of the manuscript.

\section{REFERENCES}

ANP. Boletim Mensal de Produção submetido à ANP, 2006. <www.anp.gov.br>, accessed 15 February 2007.

BROMHEAD, D.; FOSTER, J.; ATTARD, R.; FINDLAY, J.; KALISH, J. A Review of the impact of fish aggregating devices (FADs) on tuna fisheries. Final Report to Fisheries Resources Research Fund. Australia: Bureau of Rural Sciences., 2006. 121 p.

CLICKMACAE. 2007. <http://www.clickmacae.com.br/?sec= $109 \&$ pag=pagina\&cod=141 $>$ accessed 15 February 2007.

ICCAT. Report of the meeting of the ICCAT Ad Hoc Working Group on Precautionary Approach. International Commission for the Conservation of the Atlantic Tunas, 1999. 24 p. (mimeo).

JABLONSKI, S. Interações da pesca com a atividade petrolífera na bacia de Campos, Rio de Janeiro. SOBEMA - SEMINÁRIO SOBRE MEIO AMBIENTE MARINHO, 4. - Rio de Janeiro, 19 a 21 de novembro de 2003, 2003. $15 \mathrm{p}$

MARTINS, A. S.; DOXSEY, J.R. Diagnóstico da Pesca no litoral do Espírito Santo. In: ISAAC, V.; MARTINS, A.S.; HAIMOVICI, M.; ANDRIGUETTO FILHO, J.M. (Orgs.). A pesca marinha e estuarina do Brasil no início do século XXI: Recursos, tecnologias, aspectos socioeconômicos e institucionais. Belém: Editora Universitária UFPA. p. 93-116, 2006.

MARINHA DO BRASIL. NORMAM-08: Normas da Autoridade Marítima para Tráfego e Permanência de Embarcações em Águas Jurisdicionais Brasileiras , n. 8 Diretoria de Portos e Costas-DPC. Marinha do Brasil, 2000.

UNCLOS. United Nations Convention on the Law of the Sea, $\quad 1982 . \quad<h t t p: / / w w w . u n . o r g /$ Depts/los/ convention_agreements/convention_overview_convention.htm> accessed 15 February 2007 